\title{
Saline-sodic soil treated with gypsum, organic sources and leaching for successive cultivation of sunflower and rice
}

\author{
Petrônio D. dos Santos ${ }^{1}$, Lourival F. Cavalcante ${ }^{2}$, Hans R. Gheyi ${ }^{3}$, Geovani S. de Lima ${ }^{4}$, \\ Everaldo M. Gomes ${ }^{5}$ \& Francisco T. C. Bezerra ${ }^{6}$ \\ ${ }^{1}$ Universidade Federal de Campina Grande. Sumé, PB, Brasil. E-mail: agrodonato@hotmail.com - ORCID: 0000-0002-1406-924X \\ ${ }^{2}$ Universidade Federal da Paraíba/Centro de Ciências Agrárias. Areia, PB, Brasil. E-mail:lofeca@cca.ufpb.br (Corresponding author) - ORCID: 0000- \\ 0002-8827-4713 \\ ${ }^{3}$ Universidade Federal do Recôncavo da Bahia. Cruz das Almas, BA, Brasil. E-mail: hans@pq.cnpq.br - ORCID: 0000-0002-1066-0315 \\ ${ }^{4}$ Universidade Federal de Campina Grande. Pombal, PB, Brasil. E-mail: geovanisoareslima@gmail.com - ORCID: 0000-0001-9960-1858 \\ ${ }^{5}$ Instituto Federal de Educação, Ciência e Tecnologia da Paraíba. Sousa, PB, Brasil. E-mail: everaldomg2010@gmail.com - ORCID: 0000-0003-0291-0641 \\ ${ }^{6}$ Universidade Federal da Paraíba/Programa de Pós-Graduação em Agronomia. Areia, PB, Brasil. E-mail: bezerra_ftc@yahoo.com.br - ORCID: 0000- \\ 0002-9185-2641
}

\begin{abstract}
Correction of saline and sodic soils aims to reduce salts dissolved in the solution and exchangeable sodium, respectively, to allow the growth and production of crops. In this context, an experiment was carried out between August/2011 and September/2012, in saline-sodic soil of the Irrigated Perimeter of São Gonçalo, in the municipality of Sousa, PB, Brazil. Agricultural gypsum, organic sources and continuous leaching for reducing salinity, sodicity and alkalinity in the saline-sodic soil and their effects on the production of the sunflower cultivar Embrapa 122/V-2000 and the rice variety Diamante were evaluated. The treatments were distributed in four randomized blocks and the soil was subjected to continuous leaching for 50 days and evaluated for salinity, sodicity and alkalinity before and after leaching, as well after sunflower and rice cultivation, in the 0-0.20 and 0.20-0.40 m layers. Leaching and the application of gypsum and organic sources reduced the initial salinity in both soil layers, to a greater extent in the surface layer. Exchangeable sodium decreased in $0-0.20 \mathrm{~m}$ and increased in $0.20-0.40 \mathrm{~m}$. After rice cultivation, the soil in the $0-0.20 \mathrm{~m}$ layer changed from saline-sodic to non-saline in the treatments gypsum + bovine manure and gypsum + rice husk. The reduction of salinity, sodicity and alkalinity in the soil was higher during rice cultivation than during sunflower cultivation.
\end{abstract}

Key words: Helianthus annuus, correction of sodicity, salinity, soil conditioners

\section{Solo salino-sódico tratado com gesso, fontes orgânicas e lavagem para cultivos sucessivos de girassol e arroz}

RESUMO: A correção de solos salinos e sódicos objetiva reduzir os sais dissolvidos na solução e sódio trocável, respectivamente, possibilitando o crescimento e a produção das culturas. Neste contexto, um experimento foi desenvolvido, entre agosto/2011 e setembro/2012, em solo salino-sódico do Perímetro Irrigado de São Gonçalo, no município de Sousa, PB. Foram avaliados o gesso agrícola, fontes orgânicas e lavagem contínua na redução de salinidade, sodicidade e alcalinidade do solo salino-sódico e seus efeitos na produção de girassol cultivar Embrapa 122/V-2000 e arroz variedade Diamante. Os tratamentos foram distribuídos em quatro blocos casualizados, o solo foi submetido a lavagem contínua durante 50 dias e avaliado quanto à salinidade, sodicidade e alcalinidade antes e depois da lavagem, como também após os cultivos do girassol e do arroz, nas camadas de 0-0,20 e 0,20-0,40 m. A lavagem e a aplicação de gesso e fontes orgânicas reduziram a salinidade inicial em ambas as camadas do solo, em maior proporção na camada superfícial. O sódio trocável diminuiu em 0-0,20 m e aumentou em 0,20-0,40 m. O solo na camada de 0-0,20 m, após o cultivo do arroz, passou de salino-sódico para não salino nos tratamentos gesso com esterco bovino e gesso mais casca de arroz. A redução da salinidade, sodicidade e alcalinidade foi maior no solo durante cultivo de arroz do que com girassol.

Palavras-chave: Halianthus annuus, correção da sodicidade, salinidade, condicionadores do solo 


\section{INTRODUCTION}

The excess of soluble salts in irrigated areas of the Brazilian semiarid region is related to low and irregular rainfall, high evapotranspiration and anthropic actions. These factors contribute to the increase of soluble salts and exchangeable sodium, respectively in the solution and in the sorption complex, which results in salinization and sodification, compromising the physical, chemical and biological quality of the soil and with effect on plant production capacity (Corrêa et al., 2003; D'Odorico et al., 2013; Trivedi et al., 2017).

The classifications regarding soil salinity and sodicity consider the electrical conductivity of the saturation extract (ECse, $\mathrm{dS} \mathrm{m}^{-1}$ ), the exchangeable sodium percentage (ESP) in the sorption complex and the hydrogen potential $(\mathrm{pH})$. According to Richards (1954), saline soil has ECse $>4.0 \mathrm{dS}$ $\mathrm{m}^{-1}$, ESP $<15$ and $\mathrm{pH}$ between 7.0 and 8.5 , saline-sodic soil has ECse $>4.0 \mathrm{dS} \mathrm{m}^{-1}$, ESP $>15$ and $\mathrm{pH}<8.5$, while sodic soil has ECse $<4.0 \mathrm{dS} \mathrm{m}^{-1}$, ESP $>15$ and $\mathrm{pH}>8.5$. The Brazilian Soil Classification System (EMBRAPA, 2018) adopts the saline $\left(4.0 \leq\right.$ ECse $\left.\leq 7.0 \mathrm{dS} \mathrm{m}^{-1}\right)$, salic (ECse $\left.\geq 7.0 \mathrm{dS} \mathrm{m}^{-1}\right)$, solodic $\left(6.0 \leq\right.$ ECse $\left.\leq 15.0 \mathrm{dS} \mathrm{m}^{-1}\right)$ and sodic $(\mathrm{ESP} \geq 15)$ characters for classification of salt affected soils.

After salinization and/or sodification, soil correction requires the use of techniques that do not compromise the environmental quality and are economically viable (Costa et al., 2016; Chávez-García \& Siebe, 2019). Mitigating the risks of salinity and sodicity allows previously unproductive soils to return to agricultural production systems under irrigation (Gomes et al., 2000; Ahmed et al., 2015).

To reclaim soils degraded by salts, the fundamental techniques are leaching and drainage of the soil (Miranda et al., 2011; Tavares Filho et al., 2012), which can be enhanced with the use of chemical amendments. Leaching and drainage reduce salinity through the solubilization and leaching of salts, while the corrective reduces sodicity by the chemical action of mineral and organic sources (Gill et al., 2008; Sá et al., 2013; Sousa et al., 2014; Araujo et al., 2015).

Meng et al. (2019) recommend the annual application of bovine manure due to its action of reducing $\mathrm{pH}$ and electrical conductivity, increasing organic matter content and improving soil structural properties, retention, water infiltration and aggregation.

In the correction of soils degraded by salinity and/or sodicity, Chávez-García \& Siebe (2019) suggest the succession of crops due to the great importance in the phytoremediation of soils (Ado et al., 2019). In this context, the rice crop is introduced during the reclamation of saline-sodic or sodic soil (Gomes et al., 2000; Zhou et al., 2019), besides sunflower, an oilseed crop moderately tolerant to salinity (Sousa et al., 2014).

In view of the above, this study was conducted to evaluate the effects of leaching, followed by the application of gypsum and organic sources - bovine manure, rice husk and coconut fiber, alone and in combination with gypsum, on the salinity, sodicity and alkalinity of a saline-sodic soil and on the production of sunflower and rice.

\section{Material AND Methods}

The study was conducted in an Alfisol, between August/2011 and September/2012, in the Fruticulture Sector of the Instituto
Federal de Educação, Ciência e Tecnologia da Paraíba - IFPB ( $6^{\circ} 50^{\prime} 00^{\prime \prime} \mathrm{S} ; 38^{\circ} 19^{\prime} 00^{\prime \prime} \mathrm{W} ; 235 \mathrm{~m}$ altitude) in the Irrigated Perimeter of São Gonçalo, Sousa, PB, Brazil, under hot and dry climate (Alvares et al., 2013) with average values of annual rainfall, evaporation, temperature and relative humidity, in the years 2011 and 2012, of 1,346 and $544 \mathrm{~mm}, 1,854$ and 2,419 $\mathrm{mm}, 25.5$ and $25.6^{\circ} \mathrm{C}$, and 80 and $62 \%$, respectively.

The experimental design was randomized blocks, with eight treatments and four repetitions, dimensioned in $7.5 \mathrm{~m}$ x 7.0 m plots, as follows: C - control (without any treatment); $\mathrm{G}$ - agricultural gypsum; BM - bovine manure; $\mathrm{RH}$ - rice husk; $\mathrm{CF}$ - coconut fiber; $\mathrm{G}+\mathrm{BM}$ - gypsum + bovine manure; $\mathrm{G}+$ $\mathrm{RH}$ - gypsum + rice husk; $\mathrm{G}+\mathrm{CF}$-gypsum + coconut fiber. The experimental design was a split-plot scheme, in which the main plot was represented by chemical and/or organic treatments for soil reclamation while the subplots were represented by the soil depths. Each stage of the experiment was evaluated in two periods and, therefore, they were considered as evaluations repeated in time.

Four single samples of the saline-sodic soil were randomly collected in the 0-0.20 and 0.20-0.40 m layers in each plot, transformed into a composite sample and the mean value was used for soil characterization before starting the experiment.

The chemical evaluations regarding the contents of total soil cations and soluble cations in the saturation extract and the physical characterization of the soil were carried out according to the methodologies contained in Richards (1954). The contents of cations adsorbed on the clay complex, for determination of cation exchange capacity $\left[\mathrm{Ca}^{2+}+\mathrm{Mg}^{2+}+\mathrm{K}^{+}\right.$ $\left.+\mathrm{Na}^{+}+\left(\mathrm{Al}^{3+}+\mathrm{H}^{+}\right)\right]$, were obtained using the extractor $1 \mathrm{M}$ ammonium acetate at $\mathrm{pH}$ 7. The exchangeable cation content used in the determination of the cation exchange capacity was quantified by the difference between the total content of the cation extracted and the content determined in the saturation extract. Available phosphorus was determined by the method of $0.5 \mathrm{M}$ sodium bicarbonate at $\mathrm{pH} 8.5$, known as the Olsen extractor (Olsen \& Sommers, 1982). Salinity was evaluated by the electrical conductivity of the saturated paste extract in 300 -g soil sample $(<2.0 \mathrm{~mm})$, recording the volume of water applied until to the saturation state, keeping them at rest for $12 \mathrm{~h}$ to obtain the extract for the determination of the contents of soluble cations $\left(\mathrm{Ca}^{2+}, \mathrm{Mg}^{2+}, \mathrm{K}^{+}, \mathrm{Na}^{+}\right)$. The presence of free carbonate in the samples was assessed by adding hydrochloric acid to the moist soil (Freire et al., 2016). Saturated paste $\mathrm{pH}$ was measured using a $\mathrm{pH}$ meter calibrated using buffered solutions of $\mathrm{pH} 4$ and 7. Physical evaluation consisted of soil density, determined by the paraffin-coated clod method, and particle density, determined in boiling water in volumetric flask for extraction of the air. In the determination of sand, silt and clay fractions, as the soil was saline-sodic, the chemical dispersing agent used was sodium hexametaphosphate. The organic sources were characterized by wet digestion according to Silva (2009). The results of the characterizations are presented in Table 1.

The dose of agricultural gypsum $\left(\mathrm{CaSO}_{4} \cdot 2 \mathrm{H}_{2} \mathrm{O}\right)$, originating from gypsite deposits, of 9,000 $\mathrm{kg} \mathrm{ha}^{-1}$ was calculated based on data from the $0-0.20 \mathrm{~m}$ layer (Table 1 ) and incorporated in the entire area of the plot to $0.15 \mathrm{~m}$ depth, calculated by the 
Table 1. Fertility, salinity and physical attributes of the Alfisol and chemical attributes of the organic sources used in the experiment

\begin{tabular}{|c|c|c|c|c|c|c|c|c|c|c|}
\hline \multicolumn{11}{|c|}{ Soil attributes } \\
\hline Fertility $^{1}$ & \multicolumn{3}{|c|}{$0-0.20$ and $0.20-0.40 \mathrm{~m}$} & \multicolumn{2}{|c|}{ Salinity $^{2}$} & \multicolumn{2}{|c|}{$0-0.20$ and $0.20-0.40 \mathrm{~m}$} & Physical $^{3}$ & \multicolumn{2}{|c|}{$0-0.20$ and $0.20-0.40 \mathrm{~m}$} \\
\hline $\mathrm{pH}$ in water $(1: 2$. & \multicolumn{3}{|c|}{8.52 and 8.97} & \multicolumn{2}{|c|}{$\mathrm{pHsp}$} & \multicolumn{2}{|c|}{8.18 and 8.92} & Sand $\left(\mathrm{g} \mathrm{kg}^{-1}\right)$ & \multicolumn{2}{|c|}{710 and 633} \\
\hline SOM $\left(\mathrm{g} \mathrm{kg}^{-1}\right)$ & \multicolumn{3}{|c|}{8.00 and 7.00} & \multicolumn{2}{|c|}{ ECse $\left(\mathrm{dS} \mathrm{m}^{-1}\right)$} & \multicolumn{2}{|c|}{4.64 and 4.20} & Silt $\left(\mathrm{g} \mathrm{kg}^{-1}\right)$ & \multicolumn{2}{|c|}{155 and 179} \\
\hline $\mathrm{Ca}^{2+}\left(\mathrm{cmol}_{\mathrm{c}} \mathrm{kg}^{-1}\right)$ & \multicolumn{3}{|c|}{4.93 and 5.14} & \multicolumn{2}{|c|}{$\mathrm{Ca}^{2+}\left(\mathrm{mmol}_{\mathrm{c}} \mathrm{L}^{-1}\right)$} & \multicolumn{2}{|c|}{1.02 and 1.11} & Clay $\left(\mathrm{g} \mathrm{kg}^{-1}\right)$ & \multicolumn{2}{|c|}{135 and 188} \\
\hline $\mathrm{Mg}^{2+}\left(\mathrm{cmol}_{\mathrm{C}} \mathrm{kg}^{-1}\right.$ & \multicolumn{3}{|c|}{3.61 and 3.71} & \multicolumn{2}{|c|}{$\mathrm{Mg}^{2+}\left(\mathrm{mmol}_{\mathrm{c}} \mathrm{L}^{-1}\right)$} & \multicolumn{2}{|c|}{2.35 and 2.52} & WDC $\left(\mathrm{g} \mathrm{kg}^{-1}\right)$ & \multicolumn{2}{|c|}{86 and 42} \\
\hline $\mathrm{Na}^{+}\left(\mathrm{cmol}_{\mathrm{c}} \mathrm{kg}^{-1}\right)$ & \multicolumn{3}{|c|}{4.33 and 4.76} & \multicolumn{2}{|c|}{$\mathrm{Na}^{+}\left(\mathrm{mmol}_{\mathrm{c}} \mathrm{L}^{-1}\right)$} & \multicolumn{2}{|c|}{43.41 and 37.87} & Ds $\left(\mathrm{kg} \mathrm{dm}^{-3}\right)$ & \multicolumn{2}{|c|}{1.52 and 1.58} \\
\hline $\mathrm{K}^{+}\left(\mathrm{cmol}_{\mathrm{c}} \mathrm{kg}^{-1}\right)$ & \multicolumn{3}{|c|}{0.17 and 0.18} & \multicolumn{2}{|c|}{$\mathrm{K}^{+}\left(\mathrm{mmol}_{\mathrm{c}} \mathrm{L}^{-1}\right)$} & \multicolumn{2}{|c|}{0.22 and 0.24} & $\mathrm{Dp}\left(\mathrm{kg} \mathrm{dm}^{-3}\right)$ & \multicolumn{2}{|c|}{2.69 and 2.69} \\
\hline $\mathrm{SB}\left(\mathrm{cmol}_{\mathrm{c}} \mathrm{kg}^{-1}\right)$ & \multicolumn{3}{|c|}{13.04 and 13.79} & \multicolumn{2}{|c|}{$\mathrm{Cl}^{-}\left(\mathrm{mmol}_{\mathrm{C}} \mathrm{L}^{-1}\right)$} & \multicolumn{2}{|c|}{ ND and ND } & $\mathrm{Pt}(\%)$ & \multicolumn{2}{|c|}{43 and 41} \\
\hline$\left(\mathrm{H}^{+}+\mathrm{Al}^{3+}\right)(\mathrm{cmo}$ & & 0 and 0 & & & $\left.\mathrm{~mol}_{\mathrm{C}} \mathrm{L}^{-1}\right)$ & Pres & & $U_{1}\left(\mathrm{~g} \mathrm{~kg}^{-1}\right)$ & & 12.6 \\
\hline CEC $\left(\mathrm{cmol}_{\mathrm{C}} \mathrm{kg}^{-1}\right)$ & & 4 and 1 & & & $\left.\mathrm{~mol}_{\mathrm{C}} \mathrm{L}^{-1}\right)$ & & & $\mathrm{U}_{2}\left(\mathrm{~g} \mathrm{~kg}^{-1}\right)$ & & 5.11 \\
\hline$V(\%)$ & & 00 and 1 & & & $\left.\left.n o\right|_{C} L^{-1}\right)$ & & & Aw $\left(g^{k g}{ }^{-1}\right)$ & & 7.49 \\
\hline ESP (\%) & & 1 and 3 & & SA & $\mathrm{nol} \mathrm{L-1})^{1 / 2}$ & 33.4 & 8.11 & & & \\
\hline Classification & & it. and $\mathrm{E}$ & & Cla & ation & & & & & \\
\hline Organic & & $\mathrm{OM}$ & $\bar{C}$ & $\overline{\mathrm{N}}$ & & $\mathrm{Ca}^{2+}$ & $\mathrm{Mg}^{2+}$ & $\mathrm{Na}^{+}$ & $\overline{\overline{K^{+}}}$ & $\overline{\mathbf{P}}$ \\
\hline sources $^{4}$ & pH In water & & $\overline{\left(\mathrm{g} \mathrm{kg}^{-1}\right)}$ & & $\mathbf{U} / \mathbf{N}$ & & $\mathrm{cmol}_{\mathrm{c}} \mathrm{kg}$ & & & \\
\hline Bovine manure & 7.89 & 661.0 & 383.4 & 16.5 & $1: 23$ & 6.7 & 5.9 & 15.4 & 6,277 & 3.927 \\
\hline Rice husk & 6.00 & 710.6 & 412.2 & 4.6 & $1: 89$ & 2.4 & 2.4 & 3.1 & 1,277 & 229 \\
\hline Coconut fiber & 4.91 & 831.5 & 482.3 & 3.9 & $1: 124$ & 1.1 & 1.0 & 3.6 & 1,500 & 25 \\
\hline
\end{tabular}

${ }^{1}$ Determined in air-dried soil sample; SOM - soil organic matter, Walkley-Black method; P - Olsen Extract; $\mathrm{SB}-\mathrm{Sum}$ of exchangeable bases $\left(\mathrm{Ca}^{2+}+\mathrm{Mg}^{2+}+\mathrm{K}^{+}+\mathrm{Na}^{+}\right)$; $\mathrm{CEC}-$ cation exchange capacity $\left[\mathrm{SB}+\left(\mathrm{H}^{+}+\mathrm{Al}^{3+}\right) ; \mathrm{V}\right.$ - Percentage of saturation by exchangeable bases [(SB/CEC) x 100]; ESP - Exchangeable sodium percentage $\left(\right.$ Exchangeable Na $\left.\left.{ }^{+} / \mathrm{CEC}\right) \mathrm{x} 100\right]$ ${ }^{2}$ Determined in the saturated paste extract; pHsp - pH of saturated paste; ECse - Electrical conductivity of the soil saturation extract; Ent - Entrophic; ND - Not determined; Pres. Present; SAR - Sodium adsorption ratio (soluble cations) $\left[\mathrm{Na}^{+} /\left(\mathrm{Ca}^{2+}+\mathrm{Mg}^{2+}\right) / 2\right]^{1 / 2}$; SS - Saline-sodic, classification according to Richards (1954)

${ }^{3} \mathrm{WDC}$ - Water-dispersible clay; Ds and Dp - Soil density and particle density; Pt - Total porosity [Pt = (1-Ds/Dp) $\left.\mathrm{x} 100\right] ; \mathrm{U}_{1}$ and $\mathrm{U}_{2}$ - Volumetric soil moisture at tensions of - $0.01 \mathrm{MPa}$ and -1.50 MPa; Aw - Available water

${ }^{4}$ Analyses conducted according to Silva (2009)

expression: Td = (ESPi-ESPd $) \times$ CEC $\times$ Z $x$ Ds $x$ EqW/100) $\mathrm{x}$ $(1+\mathrm{U} / 100)$ (Pizarro, 1978). In which: $\mathrm{Td}=$ theoretical dose $\left(\mathrm{kg} \mathrm{ha}^{-1}\right), \mathrm{ESPi}=$ exchangeable sodium percentage in the soil before application of inputs and leaching; ESPd = desired exchangeable sodium percentage in the soil (10\%); CEC = cation exchange capacity $\left(\mathrm{cmol}_{\mathrm{c}} \mathrm{dm}^{-3}\right) ; \mathrm{Z}=$ soil depth to be reclaimed $(\mathrm{cm})$; Ds = soil density $\left(\mathrm{kg} \mathrm{dm}^{-3}\right) ; \mathrm{EqW}=$ equivalent weight of gypsum (86); $U$ = moisture on mass basis (\%) in the gypsum. The practical dose - PD, according to Pizarro (1978), was summed with $25 \%$ of the theoretical dose of gypsum and $5 \%$ of the moisture that the chemical corrective contained.

The effects of continuous leaching, agricultural gypsum, bovine manure, rice husk and coconut fiber were evaluated separately and in combination for the reduction of salinity, sodicity and alkalinity in the $0-0.20$ and $0.20-0.40 \mathrm{~m}$ layers of a saline-sodic soil. The evaluations were carried out in three stages: before and after soil leaching (Stage 1), after soil leaching and cultivation of sunflower (Helianthus annuus), cv Embrapa 122/V-2000 (Stage 2), and after cultivation of rice (Oryza sativa), Diamante variety (Stage 3), grown in succession to sunflower, both with cultivation cycle of approximately 100 days.

Before starting the study, the soil of the experimental area was subjected to a subsoiling to $0.50 \mathrm{~m}$ depth, followed by plowing and harrowing in the $0-0.30 \mathrm{~m}$ layer. Then, underground drains of PVC pipe with nominal diameter of $75 \mathrm{~mm}$, spaced by $9.0 \mathrm{~m}$, were installed between blocks and on each margin (border) of the experimental area at $0.90 \mathrm{~m}$ depth, in 0.30-m-wide, 70-m-long furrows with $2 \%$ slope in the transverse direction of the collector drain of the Irrigated Perimeter, in the Fruticulture Sector of IFPB, Sousa, PB, Brazil.

The organic sources were incorporated in all plots, alone or in combination with gypsum, according to the treatments. Bovine manure was adopted as a reference, applying $3,834 \mathrm{~kg}$ $\mathrm{ha}^{-1}$ of organic carbon, referring to $10,000 \mathrm{~kg} \mathrm{ha}^{-1}$ of the input, for being the most used in agriculture, $9,301 \mathrm{~kg} \mathrm{ha}^{-1}$ of rice husk and $7,949 \mathrm{~kg} \mathrm{ha}^{-1}$ of coconut fiber, in order to provide the same values of organic carbon among these inputs.

After incorporation of gypsum and organic sources, containment dikes were built around each plot for the application of the water $\left[\mathrm{EC}=0.37 \mathrm{dS} \mathrm{m}^{-1}\right.$ and $\mathrm{SAR}=1.19$ $\left(\mathrm{mmol} \mathrm{L}^{-1}\right)^{0.5}$. The soil was previously saturated and then a $10 \mathrm{~cm}$ water depth was maintained for continuous soil leaching for 50 days, according to Gomes et al. (2000).

At the end of the leaching, in September/2011 (Stage 1), at the harvests of sunflower in January/2012 (Stage 2) and rice in June/2012 (Stage 3), soil samples were collected in each plot for the characterization with respect to the electrical conductivity of the saturation extract (ECse - salinity), exchangeable sodium percentage (ESP - sodicity) and hydrogen potential of the saturated paste ( $\mathrm{pHsp}$ - alkalinity), using the same criterion of the initial soil sampling, in the layers of $0-0.20$ and $0.20-0.40 \mathrm{~m}$.

Sunflower was sown at $1.0 \times 0.60 \mathrm{~m}$ spacing $\left(16,667\right.$ plants ha $\left.^{-1}\right)$ and fertilization was carried out according to the recommendation of EMPARN (2009), providing triple superphosphate, potassium sulfate, urea and boric acid for soil without salinity problems. Irrigation was applied by micro-sprinklers, with flow rate of $70 \mathrm{~L} \mathrm{~h}^{-1}$ and uniformity of $92 \%$, installed at $4 \times 4$ $\mathrm{m}$ spacing. The applied water depth was calculated based on the potential evapotranspiration obtained from class A pan, with a 0.75 factor, and considering crop coefficients $(\mathrm{kc})$ of $0.3,0.8,1.1$ and 0.7 , for the first 30 days, from 30 to 45 , from 45 to 80 and from 81 to 100 days, respectively (Doorenbos \& Kassam, 2000).

Rice was grown at spacing of $0.30 \mathrm{~m}$ between rows and $0.10 \mathrm{~m}$ between plants in the rows, two plants per hole, with a stand of 66.600 plants per hectare. In the first 30 days after transplanting, irrigation was based on the evapotranspiration estimated from the class A pan, using micro-sprinklers. From 30 to 80 days after transplanting, grain filling period, irrigation 
was applied by intermittent flooding, maintaining a minimum water depth of $0.05 \mathrm{~m}$. Fertilization was carried out at tillering and at booting stage, as performed by Gomes et al. (2000).

The data were subjected to likelihood analysis using the $\mathrm{F}$ test ( $\mathrm{p} \leq 0.05$ ) to evaluate the effects of treatments on soil reclamation (0-0.20 and $0.20-0.40$ m layers) in two periods of evaluation, relative to the soil before and after leaching (Stage 1), after leaching and cultivation of sunflower (Stage 2 ), after cultivation of sunflower and rice (Stage 3 ). The means were compared by Tukey test at $\mathrm{p} \leq 0.05$. The analyses were performed in the program SAS University Edition.

\section{Results AND Discussion}

According to the results of the likelihood analysis, the interaction between treatments and evaluation time $(\mathrm{F}=3.03$; $\mathrm{p}=0.0101$ ) (referring to the soil before and after leaching) had an effect on the electrical conductivity of the saturation extract (ECse), in Stage 1 and also between the profile layers ( $\mathrm{F}=13.77$; $\mathrm{p}=0.0011$ ). The exchangeable sodium percentage (ESP) was influenced by the interactions between evaluation time and depth $(\mathrm{F}=185.60 ; \mathrm{p}<0.0001)$ and between treatments and soil depths $(\mathrm{F}=7.02 ; \mathrm{p}=0.0001)$. In Stage 2 , the interaction of treatments $\times$ evaluation stages $\times$ soil depths significantly affected soil salinity (ECse) $(\mathrm{F}=4.09 ; \mathrm{p}=0.0014)$ and sodicity $(\mathrm{ESP})(\mathrm{F}=3.61 ; \mathrm{p}=0.0033)$. In Stage 3, ECse responded to the effects of the interaction between evaluation stages and soil depth $(F=15.99 ; \mathrm{p}=0.0002)$ and the ESP responded to the interaction between treatments and depth $(\mathrm{F}=10.11$; $<0.0001)$ and to the single action of the evaluation stages. Regarding alkalinity, the $\mathrm{pH}$ of the saturated paste ( $\mathrm{pHsp}$ ), except for the soil depths $(\mathrm{p}<0.05)$, did not vary as a function of the treatments, different evaluation stages or any of the studied interactions.

Continuous soil inundation for 50 days, despite promoting the leaching of salts in all treatments (Figure 1A) did not differ in the cases of the soil with gypsum $(G)$, gypsum + bovine manure $(G+B M)$ and gypsum + rice husk $(G+R H)$. The results are consistent with those found in the literature (Gill et al., 2008; Miranda et al., 2011; Araújo et al., 2015), in which the gypsum alone or associated with organic matter influences the leaching of salts in soils degraded by sodicity. The lack of significant effect of the respective treatments can be a response of the low solubility of gypsum, around $2.5 \mathrm{~g} \mathrm{~L}^{-1}$ (Pizarro, 1978). In addition, the period under continuous leaching in the field may not have been sufficient for complete solubilization of gypsum and organic inputs and, consequently, for the leaching of the dissolved salts.

For the electrical conductivity of the soil saturation extract, before and after leaching, the treatments did not differ. However, there was an average reduction of ECse from 4.41 to $2.98 \mathrm{dS} \mathrm{m}^{-1}$, indicating a $32.42 \%$ leaching of salts considering the values before and after soil leaching recorded in Stage 1.

Despite the average leaching of $32.42 \%$, it was verified that the higher concentration of salts (ECse) occurred in the layer of $0-0.20 \mathrm{~m}$ compared to $0.20-0.40 \mathrm{~m}$. The ratio between the average values of these depths, 4.03 and $3.37 \mathrm{dS} \mathrm{m}^{-1}$ (Figure $1 \mathrm{~B})$, expresses a superiority of $19.58 \%$ in the superficial layer. Compared to the average data of the soil, in the abovementioned layers before leaching, 4.64 and $4.20 \mathrm{dS} \mathrm{m}^{-1}$ (Table 1), the average leaching in each depth was lower, equal to 13.14 and $19.76 \%$. Higher ECse and lower leaching in the first layer may be due to the incorporation of the inputs in the $0-0.15 \mathrm{~m}$ soil layer and, although there was solubilization, the leaching

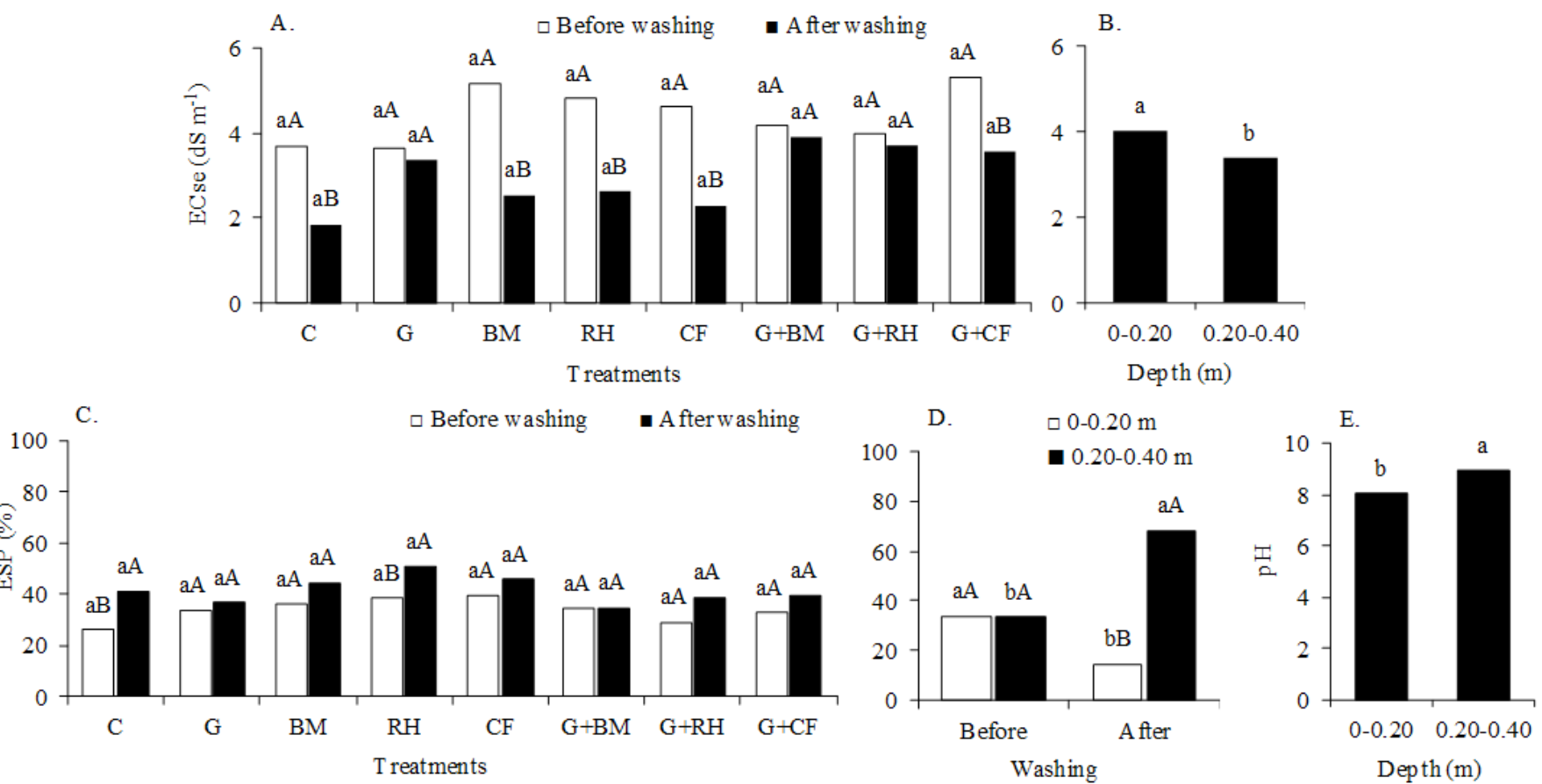

B.

Means followed by the same letter, lowercase between bars with the same color and uppercase between bars with different colors, do not differ by Tukey test at $\mathrm{p} \leq 0.05$. C - control (without treatment); G- agricultural gypsum; BM- bovine manure; RH- Rice husk; CF - coconut fiber; G + BM - gypsum + bovine manure; G + RH - gypsum + rice husk; G + CF - gypsum + coconut fiber

Figure 1. Electrical conductivity of the soil saturated paste extract in the interaction between treatments and evaluation time (A), between depths (B); exchangeable sodium percentage before and after leaching (C) and between depths (D), and pH values between soil layers (E) 
of salts was not sufficient to promote a greater reduction in the electrical conductivity of soil saturation extract.

The exchangeable sodium percentage, despite not differing between treatments in the 0-0.20 and 0.20-0.40 m layers, with mean values of 24.1 and $50.8 \%$, was significantly higher (110.79\%) in the $0.20-0.40 \mathrm{~m}$ layer (Figure 1D). By relating these values with those of the soil in each layer before leaching (Table 1), it can be observed that after leaching the ESP was reduced by $28.27 \%$ in the superficial layer $(0-0.20 \mathrm{~m})$ and increased by $51.64 \%$ in the subsequent layer $(0.20-0.40 \mathrm{~m})$. This situation, between the layers, according to Richards (1954), Gomes et al. (2000) and Sá et al. (2013), indicates greater release of calcium to substitute sodium, reduction of sodicity in the superficial layer and lower release of the cation in the subsequent layer, contributing to increased sodicity. Thus, the 50-day period of continuous leaching may not have been sufficient for the release of calcium from the gypsum and from the organic sources, to replace sodium in the sorption complex and to reduce sodicity, as indicated by the values of exchangeable sodium percentage. This situation is also in conformity with the data of Figure 1D, in which the initial ESP of the soil before leaching was reduced from 33.6 to $14.5 \%$ and increased from 33.5 to $68.1 \%$, respectively in the layers of $0-0.20$ and $0.20-0.40 \mathrm{~m}$, also reflecting that sodium leaching was lower in the subsurface layer of the soil.

Alkalinity was significantly higher in the 0.20-0.40 m layer, with pHsp variation from 8.0 to 8.9 (Figure 1E), which are consistent with ESP and are of the same order of the values 8.18 and 8.92 , for the soil before application of the treatments (Table 1). The effect of the application of organic carbon on the reduction of soil salinity, sodicity and alkalinity is associated with the continuous supply of a source, as recorded by Meng et al. (2019). Organic sources reduce sodicity mainly by increasing cation exchange capacity (Meng et al., 2016).

In the period between the end of leaching and sunflower harvest (Stage 2), according to the average ECse values of 3.41 and $3.45 \mathrm{dS} \mathrm{m}^{-1}$, and 2.54 and $2.71 \mathrm{dS} \mathrm{m}^{-1}$ in the layers of $0-0.20$ and $0.20-0.40 \mathrm{~m}$, respectively, the soil had greater accumulation of salts in the superficial layer in both evaluations (Figure 2A). Thus, higher values of ECse in soil surface, similar to those
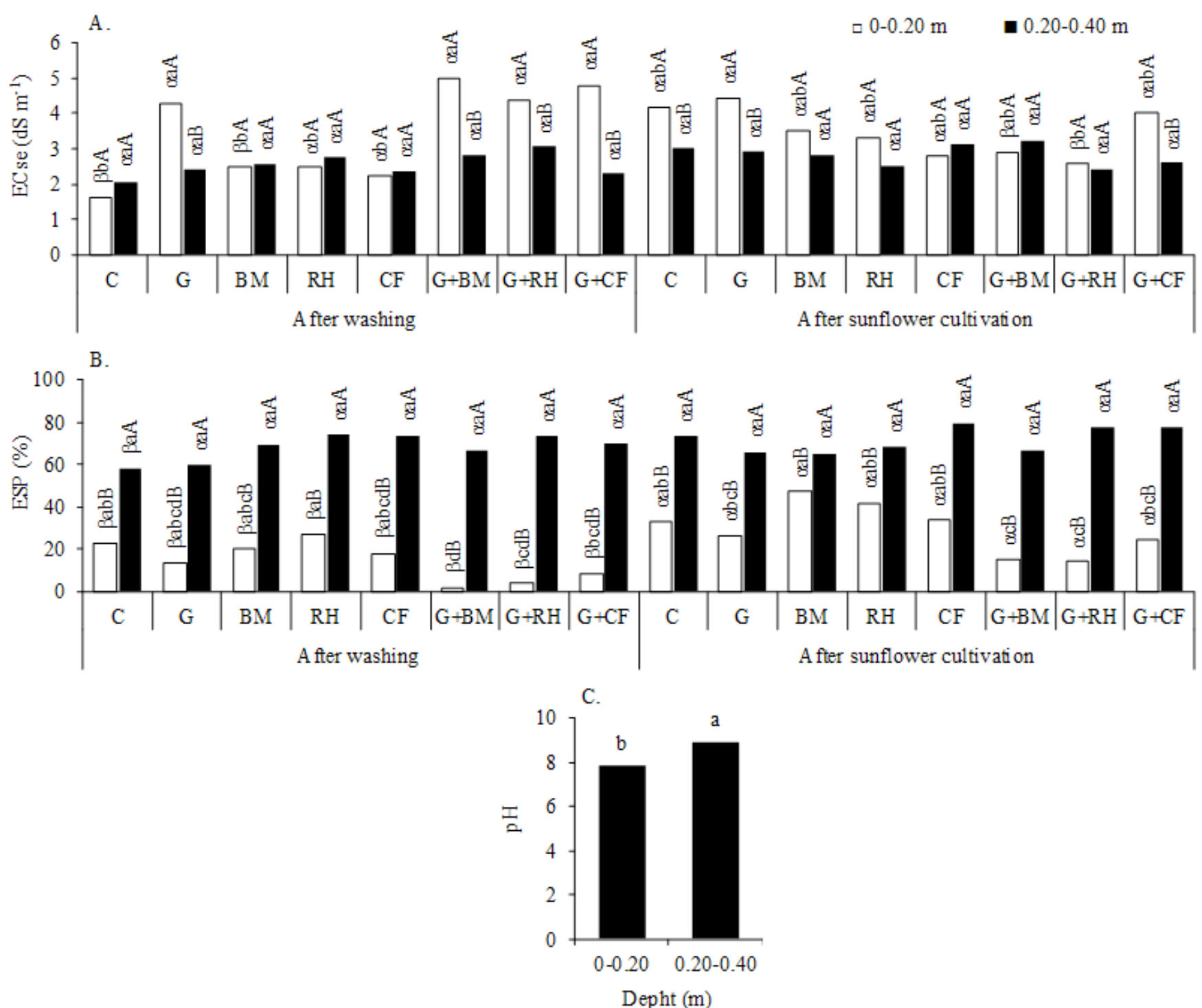

Means followed by the same letter, lowercase between bars with the same color, uppercase between bars with different colors and Greek letters between leaching and sunflower cultivation, do not differ by Tukey test at $\mathrm{p} \leq 0.05$. C - control (without treatment); G - agricultural gypsum; BM - bovine manure; RH - Rice husk; CF - coconut diber; G + BM gypsum + bovine manure; $\mathrm{G}+\mathrm{RH}$ - gypsum + rice husk; G + CF - gypsum + coconut fiber

Figure 2. Electrical conductivity of the saturated paste extract (A) and exchangeable sodium percentage (B) in the interaction between evaluation time, treatment and soil depth, and $\mathrm{pH}$ of the saturated paste at the different depths (C) 
obtained after leaching, may have been due to the absence of leaching because the water depths applied were calculated based on crop evapotranspiration as it does not tolerate soil with a high moisture content for a long time (Loose et al., 2017). The efficiency of gypsum and organic matter in reducing soil salinity may be more related to the reaction time than the applied mass. Sousa et al. (2014) observed greater reduction of salinity only in the second cycle of rotation of sunflower followed by cowpea, with application of $10 \mathrm{tha}^{-1}$ of gypsum and $20 \mathrm{tha}^{-1}$ of organic matter, that is, a reduction greater than that recorded with the supply of double these inputs.

In a comparison between the values of the first and the second depth, it can be noted that the amounts of salts in surface are 34.3 and $38.4 \%$ greater than those in the $0.20-0.40$ $\mathrm{m}$ layer, immediately after leaching and sunflower harvesting, respectively. The superiority in the surface layer after leaching results from the solubilization of salts existing in the soil, gypsum and each organic source (Table 1), and also from the release of sodium, which was replaced by calcium in the exchange complex, displaced to the soil solution and not leached to the subsequent layer.

Sodicity increased in the final period of leaching at the end of sunflower cultivation (Stage 2) between the soil layers of 0-0.20 and of $0.20-0.40 \mathrm{~m}$, with significant superiority between the treatments after sunflower harvesting in comparison to the leaching in the $0-0.20 \mathrm{~m}$ layer, but without differing in the same treatments and conditions in the layer of $0.20-0.40$ $\mathrm{m}$ (Figure 2B).

The mean values of ESP among the treatments were 14.6 and $68.1 \%, 29.6$ and $71.7 \%$, respectively in the layers of $0-0.20$ and from $0.20-0.40 \mathrm{~m}$ after leaching and sunflower harvesting. By comparing 29.6 with $14.6 \%$ and 71.7 with $68.1 \%$, it can be noted that there were increments of $102.7 \%$ in the sodicity in surface and only $5.3 \%$ in the $0.20-0.40 \mathrm{~m}$ layer, respectively after soil leaching and after sunflower harvesting. Despite the small increment of 5.3\%, the absolute values express great superiority in the deeper layer between soil leaching and sunflower harvesting.

The superiority of ESP in the $0.20-0.40 \mathrm{~m}$ layer is due to the little substitution of the sodium adsorbed on the soil by the calcium released by gypsum, by the gypsum + organic inputs complex and by each organic source alone. In terms of alkalinity, the mean $\mathrm{pH}$ values of the saturated paste, 7.8 and 8.9, in the layers of $0-0.20$ and $0.20-0.40 \mathrm{~m}$ (Figure 2C), are compatible with the higher sodicity in the deeper soil layer. These results agree with those reported by Gomes et al. (2000), Gill et al. (2008) and Ahmed et al. (2015), regarding the reduction in soil ESP caused by leaching, incorporation of gypsum, organic matter and both simultaneously in the superficial layer, but differ in relation to the deeper soil layer. The association of the application gypsum and organic matter has great power to reduce soil sodicity, and the efficiency is also related to the time of application (Sousa et al., 2014). Among the functions of gypsum, the most important is to increase the soluble calcium content to displace sodium to the soil solution (Tavares Filho et al., 2012; Sousa et al., 2014; Araujo et al., 2015), facilitating the leaching of this monovalent cation.

The saline condition of the soil between the end of sunflower harvest and the cultivation of rice (Stage 3 ) decreased from 3.46 to $1.86 \mathrm{dS} \mathrm{m}^{-1}$ and from 2.83 to $2.19 \mathrm{dS} \mathrm{m}^{-1}$ with salt leaching of 46.2 and $22.6 \%$, respectively in the layers of $0-0.20$ and $0.20-0.40 \mathrm{~m}$ (Figure $3 \mathrm{~A}$ ). This reduction, in both layers, was caused by the second soil leaching from 30 to 80 days, plus 50 days of continuous leaching, during the cultivation of rice, with a water depth of $0.05 \mathrm{~m}$ above the soil surface, reducing the values to the condition of non-saline soil (Richards, 1954; Pizarro, 1978; Cavalcante et al., 2016).

After rice cultivation, sodicity was still high and well above $15 \%$, except in the soil with gypsum associated with bovine manure and rice husk at 0-0.20 m (Figure 3B), with mean values of 25.3 and $68.0 \%$ between layers and variations from 19.7 to $44.4 \%$ in the $0-0.20$ m layer and from 58.2 to $77.5 \%$ in the 0.20-0.40 $\mathrm{m}$ layer. This situation indicates that at least two factors should be considered: the time may not have been sufficient to reduce the ESP to values below $15 \%$ or the inputs were not completely solubilized to release calcium to replace sodium in the soil. As recorded after sunflower harvesting, the sodicity in the $0.20-0.40 \mathrm{~m}$ layer remained almost three times higher than that in the superficial layer. Considering ECse below $4.0 \mathrm{dS} \mathrm{m}^{-1}$ and ESP in general above $15 \%$, the soil still had high levels of sodicity after rice cultivation, mainly in the deeper layer.

Compared to the initial soil sodicity of 33.6 and $33.5 \%$ in the layers of $0-0.20$ and $0.20-0.40 \mathrm{~m}$ (Table 1), the lowest ESP values in the first layer after rice cultivation were 9.1, 12.1, 19.7 and $23.8 \%$ in the soil with gypsum + rice husk, gypsum + bovine manure, gypsum + coconut fiber and gypsum alone (Figure 3B). These data are in agreement with Gomes et al.
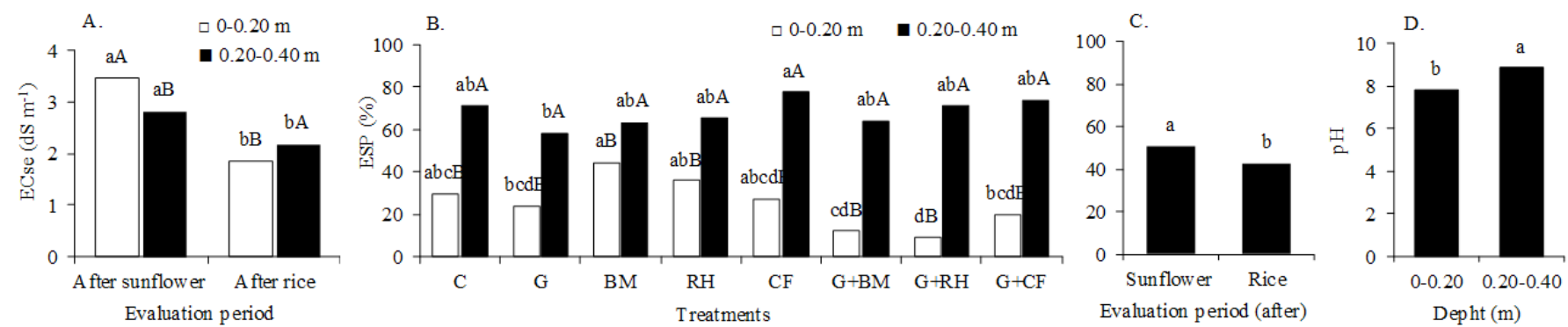

Means followed by the same letter, lowercase between bars with the same color and uppercase between bars with different colors, do not differ by Tukey test at $\mathrm{p} \leq 0.05$. C - control (without treatment); G- agricultural gypsum; BM- bovine manure; RH- Rice husk; CF- coconut fiber; G + BM- gypsum + bovine manure; G + RH- gypsum + rice husk; G + CFgypsum + coconut fiber

Figure 3. Electrical conductivity of the saturated paste extract for the interaction between evaluation periods and depths (A), exchangeable sodium percentage in the interaction between treatments and depths (B) and after rice and sunflower cultivation (C), and pHsp in the different soil layers (D) 
Table 2. Yield of sunflower achenes and rice grains in relation to the treatments

\begin{tabular}{ccccccccc}
\hline Crop & C & G & BM & RH & CF & G+BM & G+RH & G+CF \\
Sunflower $\left(\right.$ t ha $^{-1}$ ) & $0.10 \mathrm{e}$ & $0.42 \mathrm{ab}$ & $0.21 \mathrm{de}$ & $0.15 \mathrm{e}$ & $0.17 \mathrm{de}$ & $0.39 \mathrm{bC}$ & $0.31 \mathrm{~cd}$ & $0.51 \mathrm{a}$ \\
Rice $\left(\mathrm{t} \mathrm{ha}^{-1}\right.$ ) & $5.60 \mathrm{a}$ & $6.00 \mathrm{a}$ & $6.05 \mathrm{a}$ & $6.25 \mathrm{a}$ & $5.80 \mathrm{a}$ & $6.12 \mathrm{a}$ & $6.45 \mathrm{a}$ & $6.12 \mathrm{a}$ \\
\hline C - control (without any treatment); G- agricultural gypsum; & BM- bovine manure; & RH- Rice husk; CF- coconut fiber; G + BM- gypsum + bovine manure; G + RH- gypsum + rice
\end{tabular}
husk; G + CF- gypsum + coconut fiber. Means followed by the same letter, in the row, do not differ by Tukey test at $\mathrm{p} \leq 0.05$

(2000), Miranda et al. (2011), Sá et al. (2013), Sousa et al. (2014) and Ahmed et al. (2015), who found more effective action of gypsum associated with organic matter in reducing sodicity in saline-sodic soils. On the other hand, there were substantial increases in the $0.20-0.40 \mathrm{~m}$ layer, with variation from 58.2 to $77.5 \%$, resulting in increments from 73.7 to $131.3 \%$ in relation to the initial soil situation, and conflicting with those of Gomes et al. (2000) and Gill et al. (2008), who found significant reduction of sodicity in the subsurface layer of sodium-degraded soils treated with gypsum and organic matter.

The mean values of ESP, among the treatments, were reduced from 50.6 to $42.6 \%$ between the harvests of sunflower and rice (Figure $3 \mathrm{C}$ ) and indicate that soil sodicity increased compared to the initial condition (Table 1). These mean values showed an increase of sodicity compared to the soil before the application of the treatments, although the soil treated with gypsum + bovine manure and gypsum + rice husk shows sodicity below $15 \%$, evidencing that the soil changed from saline-sodic to non-saline non-sodic category. This situation, as already discussed, can be a response of the leaching of soluble salts from the respective layers without sufficient substitution of sodium by the calcium released from gypsum alone or associated with organic sources. Under these conditions, there is more sodium than calcium and magnesium with effects on the increase of sodicity, as reported by Miranda et al. (2011) and Santos et al. (2013), who studied the effects of gypsum and organic matter on the reclamation and ion dynamics of saline-sodic soils.

The mean soil alkalinity, after rice harvesting with $\mathrm{pHsp}$ of 7.8 and 8.9 , respectively, in the layers of $0-0.20$ and $0.20-0.40$ $\mathrm{m}$ (Figure 3D), is consistent with the values obtained after soil leaching and after sunflower cultivation, respectively 8.0 and 8.9 (Figure 1D) and 7.8 and 8.9 (Figure 2D). When comparing these results with those of Table 1, there was a substantial reduction of $\mathrm{pH}$ in the $0-0.20 \mathrm{~m}$ layer and maintenance of alkalinity in the subsurface soil layer. In general, differences of this magnitude are in response to the substitution of exchangeable sodium for the calcium from the inputs, displacement of sodium to the soil solution and leaching from the first to the second soil layer (Richards, 1954; Santos et al., 2013) resulting in improvement in the first layer and temporary compromised condition in the second one.

Considering the increase in the electrical conductivity of the saturated paste extract and exchangeable sodium percentage after sunflower cultivation, compared to the values after soil leaching, and the reduction after rice cultivation compared to the end of the oilseed crop cycle, it is verified that the order of rotation, after soil leaching, should be rice followed by sunflower. This consideration is due to the longer period of the soil under flooding (leaching + rice cultivation) in the sequence of rotation with rice followed by sunflower, because both the crops and the order of rotation between them can interfere with soil salinity and sodicity (Sousa et al., 2014).

Although the treatments have different effects on sunflower yield, the values of 420 to $510 \mathrm{~kg} \mathrm{ha}^{-1}$ were low (Table 2) compared to the productions from $1,991.25$ to $2,645.50$ and from 1,625 to $3,044 \mathrm{~kg} \mathrm{ha}^{-1}$ of the cultivar Catissol harvested by Sousa et al. (2014), in saline-sodic soil treated with gypsum and organic matter, in the years of 2009/2010 and 2010/2011.

Unlike sunflower, rice yield was not affected by the respective treatments, but the values of 5.60 to $6.45 \mathrm{t} \mathrm{ha}^{-1}$ are compatible with 5.75 and $5.81 \mathrm{t} \mathrm{ha}^{-1}$ and with $6.20,6.78$ and 8.81 tha $^{-1}$ in saline-sodic soils treated with gypsum and bovine manure (Gheyi et al., 1995), and with gypsum, rice husk and coconut fiber (Gomes et al., 2000), respectively.

\section{Conclusions}

1. Although leaching for 50 days reduces salinity and sodicity in the superficial soil layer, but increases in the 0.20-0.40 m layer.

2. Sunflower cultivation, after leaching the saline-sodic soil, increases salinity and sodicity.

3. Treatment of saline-sodic soil, before leaching, with gypsum plus rice husk provides the best conditions for the yield of sunflower achenes.

4. Rice cultivation by flooding reduces soil salinity and sodicity.

5. Treatments with gypsum plus bovine manure or gypsum with rice husk, after rice cultivation, reduce sodicity in soil surface.

\section{ACKNOWLeDgments}

To the National Instituto Nacional de Ciência e Tecnologia em Salinidade (INCTSal) and to the National Conselho Nacional de Desenvolvimento Científico e Tecnológico (CNPq) for granting financial resources for the execution of the project.

\section{Literature Cited}

Ado, M. N.; Michot, D.; Guero, Y.; Hallaire, V.; Lamso, N. D.; Dutin, G.; Walter, C. Echinochloastagnina improves soil structure and phytodesalinization of irrigated saline sodic Vertisols. Plant Soil, v.434, p.413-424, 2019. https://doi.org/10.1007/s11104-018-3853-9

Ahmed, K.; Qadir, G.; Jami, A. R.; Nawaz, M. Q.; Rehim, A.; Jabran, K.; Hussain, M. Gypsum and farm manure application with chiseling improve soil properties and performance of fodder beet under saline-sodic conditions. International Journal of Agriculture and Biology, v.17, p.1225-1230, 2015.

Alvares, C. A.; Stape, J. L.; Sentelhas, P. C.; Gonçalves, J. L. M.; Sparovek, G. Köppen's climate classification map for Brazil. Meteorologische Zeitschrift, v.22, p.711-728, 2013. 
Araujo, J. L.; Severo, P. J. S.; Lucena, F. T. C.; Veriato, R. G.; Paiva, K. F. Enxofre elementar ou sulfato de cálcio para remediação de solos salino-sódicos? Pesquisa Agropecuária Tropical, v.45, p.388-396, 2015. https://doi.org/10.1590/1983-40632015v4537090

Cavalcante, L. F.; Santos, R. V.; Henandez, F. F. F.; Gheyi, H. R.; Dias, T. J.; Nunes, J. C.; Lima, G. S. Recuperação de solos afetados por sais. In: Gheyi, H. R.; Dias, N. S.; Lacerda, C, F.; Gomes Filho, E. (ed.) Manejo da salinidade na agricultura: Estudos básicos e aplicados. 2 ed. Fortaleza: INCTSal, 2016. Cap. 28, p.461-477.

Chávez-García, E.; Siebe, C. Rehabilitation of a highly saline-sodic soil using a rubble barrier and organic amendments. Soil \& Tillage Research, v.189, p.176-188, 2019.

Corrêa, M. M.; Ker, J. C.; Mendonça, E. S.; Ruiz, H. A.; Bastos, R. S. Atributos físicos, químicos e mineralógicos de solos da região das Várzeas de Sousa (PB). Revista Brasileira de Ciência do Solo, v.27, p.311-324, 2003.

Costa, R. N. T.; Lacerda, C. F.; Silva, L. A. C.; Araújo, A. P. B.; Araújo, J. C.; Souza, C. H. C. Indicadores da rentabilidade da recuperação de solos degradados por sais. In: Gheyi, H. R.; Dias, N. S.; Lacerda, C. F.; Gomes Filho, E. (ed.) Manejo da salinidade na agricultura: Estudos básicos e aplicados. 2.ed. Fortaleza: INCTSal, 2016. Cap.29, p.479-488.

D’Odorico, P.; Bhattachan, A.; Davis, K. F.; Ravi, S.; Runyan, C. W. Global desertification: Drivers and feedbacks. Advances in Water Resources, v.51, p.326-344, 2013. https://doi.org/10.1016/j. advwatres.2012.01.013

Doorenbos, J.; Kassam, A. H. Efeito da água no rendimento das culturas. 2.ed. Campina Grande: UFPB, 2000. 221p. FAO Estudos Irrigação e Drenagem, 33

EMBRAPA - Empresa Brasileira de Pesquisa Agropecuária. Sistema brasileiro de classificação de solos. 5.ed., rev. e ampl., Brasília, DF : Embrapa, 2018. 353p.

EMPARN - Empresa de Pesquisa Agropecuária do Rio Grande do Norte. Recomendações técnicas para o cultivo do girassol. Natal: EMPARN, 2009. 68p.

Freire, M. B. G. S.; Pessoa, L. G. M.; Gheyi, H. R. Métodos de análises químicas para solos afetados por sais. In: Gheyi, H. R.; Dias, N. S.; Lacerda, C, F.; Gomes Filho, E. (ed.) Manejo da salinidade na agricultura: Estudos básicos e aplicados. 2.ed. Fortaleza: INCTSal, 2016. Cap. 10, p.123-148.

Gheyi, H. R.; Azevedo, N. C.; Batista, M. A. F.; Santos, J. G. R. Comparação de métodos na recuperação de solo salino-sódico. Revista Brasileira de Ciência do Solo, v.19, p.173-178, 1995.

Gill, J. S.; Sale, P. W. G.; Tang, C. Amelioration of dense sodic subsoil using organic amendments increases wheat yield more than using gypsum in a high rainfall zone of Southern Australia. Field Crops Research, v.107, p.265-275, 2008. https://doi. org/10.1016/j.fcr.2008.02.014

Gomes, E. M.; Gheyi, H. R.; Silva, E. F. de F. Melhorias nas propriedades químicas de um solo salino-sódico e rendimento de arroz, sob diferentes tratamentos. Revista Brasileira de Engenharia Agrícola Ambiental, v.4, p.355-361, 2000.

Loose, L. H.; Heldwein, A. B.; Lucas, D. D. P.; Hinnah, F. D.; Bortoluzzi, M. P. Sunflower emergence and initial growth in soil with water excess. Engenharia Agrícola, v.37, p.644-655, 2017. https://doi. org/10.1590/1809-4430-eng.agric.v37n4p644-655/2017
Meng, Q. F.; Li, D. W.; Zhang, J.; Zhou, L. R.; Ma, X. F.; Wang, H. Y.; Wang, G. C. Soil properties and corn (Zea mays L.) production under manure application combined with deep tillage management in solonetzic soils of Songnen Plain, Northeast China. Journal of Integrative Agriculture, v.15, p.879-890, 2016.

Meng, Q. F.; Ma, X.; Zhang, J.; Yu, Z. The long-term effects of cattle manure application to agricultural soils as a natural-based solution to combat salinization. Catena, v.175, p.193-202, 2019. https://doi. org/10.1016/j.catena.2018.12.022

Miranda, M. A.; Oliveira, E. E. M. de; Santos, K. C. F.; Freire, M. B. G. S.; Almeida, B. G. de. Condicionadores químicos e orgânicos na recuperação de solo salino-sódico em casa de vegetação. Revista Brasileira de Engenharia Agrícola e Ambiental, v.15, p.484-490, 2011. https://doi.org/10.1590/S1415-43662011000500008

Olsen, S. R; Sommers, L. E. Phosphorus. In: Page, A. L. (ed.) Methods of soil analysis: Chemical and microbiological properties. 2.ed. Madison: Soil Science Society of America, 1982. Cap. 24, p.403430.

Pizarro, F. Drenaje agricola y recuperación de suelos salinos. Madrid: Editora Agrícola Española, 1978. 521p.

Richards, L. A. Diagnóstico y rehabilitación de suelos salinos y sódicos. Washington: USDA, 1954.172p. Manual de Agricultura, 60

Sá, F. V. S.; Araújo, J. L.; Novaes, M. C.; Silva, A. P.; Pereira, F. H. F.; Lopes, K. P. Crescimento inicial de arbóreas nativas em solo salino-sódico do Nordeste brasileiro tratado com corretivos. Revista Ceres, v.60, p.388-396, 2013.

Santos, M. A.; Freire, M. B. G. F.; Almeida, B. G.; Lins, C. M. T.; Silva, E. M. Dinâmica de íons em solo salino-sódico sob fitorremediação com Atriplex nummularia e aplicação de gesso. Revista Brasileira de Engenharia Agrícola e Ambiental, v.17, p.397-404, 2013. https://doi.org/10.1590/S1415-43662013000400007

Silva, F. C. Manual de análises químicas de solos, plantas e fertilizantes. 2.ed. Brasília: Embrapa Informação Tecnológica, 2009. 627p.

Sousa, C. H. C.; Lacerda, C. F.; Silva, F. L. B.; Neves, A. L. R.; Costa, R. N. T.; Gheyi, H. R. Yield of cotton/cowpea and sunflower/ cowpea crop rotation systems during the reclamation process of a saline-sodic soil. Engenharia Agrícola, v.34, p.867-876, 2014. https://doi.org/10.1590/S0100-69162014000500006

Tavares Filho, A. N.; Barros, M. F. C.; Rolim, M. M.; Silva, E. F. F. Incorporação de gesso para correção da salinidade e sodicidade de solos salino-sódicos. Revista Brasileira de Engenharia Agrícola e Ambiental, v.16, p.247-252, 2012. https://doi.org/10.1590/S141543662012000300002

Trivedi, P.; Singh, K.; Pankaj, U.; Verma, S. K.; Verma, R. K.; Patra, D. D. Effect of organic amendments and microbial application on sodic soil properties and of an aromatic crop. Ecological Engineering, v.102, p.127-136, 2017. https://doi.org/10.1016/j. ecoleng.2017.01.046

Zhou, M.; Liu, X.; Meng, Q.; Zeng, X.; Zhang, J.; Li, D.; Wang, J.; $\mathrm{Du}, \mathrm{W}$; $\mathrm{Ma}, \mathrm{X}$. Additional application of aluminum sulfate with different fertilizers ameliorates saline-sodic soil of Songnen Plain in Northeast China. Journal of Soils and Sediments, v.19, p.1-13, 2019. https://doi.org/10.1007/s11368-019-02311-9 